Copyright (C) 2021 University of Bucharest

Printed in Romania. All rights reserved

ISSN print: $1224-5984$

ISSN online: $2248-3942$
Rom Biotechnol Lett. 2021; 26(6): 3095-3101

doi: $10.25083 / \mathrm{rbl} / 26.6 / 3095-3101$

Received for publication, September, 1, 2021

Accepted, November, 8, 2021

Original paper

\title{
Selection of a suitable viral DNA extraction method for Sheeppox virus in cell culture
}

\author{
PIYALI MONDAL, C L PATEL, RACHNA SAGAR, INSHA ZAFIR, \\ JOYSHIKH SONOWAL, KAPIL DEV, KRISHNA BHARALI, NEHA SINGH, \\ BARKATHULLAH N, AMITESH DUBEY, BP MISHRA, BINA MISHRA
}

ICAR-Indian Veterinary Research Institute, Izatnagar, Bareilly, Uttar Pradesh, 243122-India

\begin{abstract}
A suitable method for the extraction of nucleic acids should be efficient, sensitive, rapid and simple. Moreover, ideally, good method should yield pure nucleic acid-free from any contaminant inhibitors. Several methods have been reported for viral deoxyribonucleic acid (DNA) isolation but limited information is available on quick and simple isolation of Sheeppox virus (SPPV) genomic DNA in cell culture. In this study, the healthy Vero cells and primary lamb testis cells were infected with SPPV strains such as SPPV-Jaipur, SPPV-Ranipet and SPPV-Roumanian Fanar (RF) and harvested when it exhibited clear cytopathic effect (CPE) in culture. Four different DNA extraction methods i.e., (i) Phenol/chloroform/Isoamyl alcohol method, (ii) Cell lysis buffer method, (iii) Proteinase-k method, and (iv) commercial nucleic acid extraction kit was used to extract optimum yield of viral genomic DNA from clarified culture supernatant of harvested SPPV virus. The DNA sample was characterized using the Nanodrop spectrophotometer and agarose gel electrophoresis. Significantly $(\mathrm{p}<0.05)$ higher yield of SPPV genomic DNA was obtained in proteinase-k method which was about 3-5 times more than other methods. Among these methods, proteinase-k protocol was found to be comparatively very effective method in terms of yield of viral genomic DNA, and was free from PCR inhibitors.
\end{abstract}

Keywords Sheeppox virus, lamb testis cell, Vero cell, DNA isolation methods, proteinase-k

To cite this article: MONDAL P, PATEL CL, SAGAR R, ZAFIR I, SONOWAL J, DEV K, BHARALI K, SINGH N, BARKATHULLAH N, DUBEY A, MISHRA BP, MISHRA B. Selection of a suitable viral DNA extraction method for Sheeppox virus in cell culture. Rom Biotechnol Lett. 2021; 26(6): 3095-3101. DOI: 10.25083/rbl/26.6/3095-3101.

$\triangle *$ Corresponding author: BINA MISHRA, ICAR-Indian Veterinary Research Institute, Izatnagar, Bareilly, Uttar Pradesh, 243122-India.

E-mail: binachauhanmishra@hotmail.com 


\section{Introduction}

Sheeppox virus (SPPV) disease is a highly infectious and contagious ovine disease caused by SPPV, which belongs to the genus Capri poxvirus, subfamily Chordopoxvirinae, and family Poxviridae [1]. SPPV is enveloped large DNA virus having the genome size approximately $150 \mathrm{kbps}$ [2]. The disease is mostly prevalent in the countries of Northern Hemisphere, Africa, the west Asian countries, India, China and Bangladesh [1, 3, 4]. Throughout the year, it causes a havoc for the shepherds and a negative influence reflected in the small ruminant livestock economy [5]. So, the virus must be detected and screened in order to be studied further and eradication. In general, the primary lamb testis cells (LTC) are suitable for adaptation and infection of SPPV in in-vitro study as the natural host for SPPV is sheep [6-8]. Researchers have also reported about adaption of SPPV in the Vero cell line [7, 9]. The characterization of nucleic acid through polymerase chain reaction (PCR) is very fundamental approach in our routine molecular biology work [10] which detects even a single copy of genome and, so it is extensively exploited in research and diagnostic field. An efficient DNA extraction method that yields pure and high quality DNA is required for the success of PCR, cloning, sequencing etc. and subsequent diagnosis of disease [11]. The reliability of DNA amplification depends on unbiased extraction procedures so that DNA should be free from any PCR inhibitors like biological or chemical substances, and contaminating materials [12]. For Poxvirus DNA $(\sim 150 \mathrm{~kb})$ isolation, several methods have been reported [13-17] but limited information is available on quick and simple isolation of viral genomic DNA from sheep pox viral infected culture. Thus, the present study was conducted to evaluate four different DNA extraction methods for obtaining the optimum yield of viral genomic DNA from SPPV-Jaipur, SPPV- Roumanian Fanar (RF), and SPPVRanipet infected primary LTCs and Vero cell line culture.

\section{Materials and Methods}

\section{Virus isolates}

The strains of SPPV such as SPPV-Jaipur, SPPVRoumanian Fanar and SPPV-Ranipet were obtained from the Biological Products Division, IVRI, Izatnagar (U.P.), India. Titration of each virus was done and calculated their multiplicity of infection (MOI).

\section{Titration of SPPV strains}

Titre of SPPV strains was determined using TCID $_{50}$ method. In a 96 well plate $2 \times 10^{4}$ cells were seeded with growth media and incubated in $\mathrm{CO}_{2}$ incubator at $37^{\circ} \mathrm{C}$ for overnight. Then observed the cells under the microscope to confirm that cells were evenly distributed and reached $>80 \%$ confluence. Prepared 1:10 serial dilution of SPPV-Jaipur, SPPV-Roumanian Fanar, and SPPV-Ranipet separately in maintenance media up to $10^{-7}$ and then transferred $100 \mu$ of the serially diluted virus in triplicate wells. The culture plate was sealed and incubated in $5 \% \mathrm{CO}_{2}$ at $37^{\circ} \mathrm{C}$. The cytopathic effect (CPE) of each virus strain was observed daily after 3 dpi and upto $10 \mathrm{dpi}$. Finally, the virus titre was calculated using Reed and Muench methods [18] and stored the virus samples at $-20^{\circ} \mathrm{C}$ till further use.

\section{Primary and cell line culture}

For primary LTC, the testis of 2.5 months old lamb was collected from slaughter house, in PBS with antibiotic. The sample was further processed under sterile condition. After washing with PBS (twice), extraneous fat tissues were removed and chopped into very small pieces with an autoclaved scissor and scalpel. Thereafter, tissues were transferred into the trypsinization flask and allow the cells to get separated with $0.25 \%$ trypsin (Sigma, USA). Sieve out the cells in sterile beaker covered with muslin cloth, collect the cells by centrifuging at 2000rpm for $5 \mathrm{~min}$ after re-suspended the pellet with fresh trypsin $(0.25 \%)$, at room temperature for $15 \mathrm{~min}$. The pellet was resuspended with growth media (EMEM) and centrifuged at $2000 \mathrm{rpm}$ for 5 min, and discard the supernatant. Finally, resuspended the pellet with gentle pipetting, and seed approximately, $10^{6}$ cells into a T-25 culture flask containing $5 \mathrm{ml}$ of EMEM media supplemented with $10 \%$ FBS. Culture flask was kept in $\mathrm{CO}_{2}$ incubator at $37^{\circ} \mathrm{C}$ with $5 \% \mathrm{CO}_{2}$ until confluent monolayer was formed.

For Vero cell line culture, cryopreserved Vero cells were obtained from Biological Products Division, ICAR-IVRI, Izatnagar (U.P.) India. Cells were revived in 10\% EMEM (Sigma, USA) and maintained in humidified $\mathrm{CO}_{2}$ incubator at $37^{\circ} \mathrm{C}$ with $5 \% \mathrm{CO}_{2}$. Next day, approximately $80-90 \%$ cells were confluent and further used for SPPV infection.

\section{SPPV infection in cell culture}

SPPV strains (SPPV-Jaipur, SPPV-Ranipet and SPPV$\mathrm{RF}$ ) were propagated in primary LTC culture while SPPVJaipur and SPPV-RF strain were also adapted and propagated in Vero cell line. The infection was given at 1.0 MOI and cells were harvested 5 dpi when approximately $80 \%$ CPE was observed. For DNA extraction, infected cells were subjected to two cycles of freezing and thawing for effective cell disruption, and thus recovered cell free virus lysate [19] by low speed centrifugation at $1820 \mathrm{~g}$ for $10 \mathrm{~min}$ at room temperature. Thereafter, the pellet of cell debris was discarded and viral supernatant from the samples were taken further for viral DNA isolation following four different protocols described below.

\section{Isolation of viral DNA from SPPV infected culture}

In this study four different DNA extraction methods for SPPV in cell culture were used and outlines of all protocols are given in Figure 1.

\section{Protocol 1: Viral DNA isolation using Phenol/ chloroform/Isoamyl alcohol method}

The SPPV was propagated in both LT/Vero cell culture. The harvested samples were clarified from cell debris by centrifugation at $1820 \mathrm{~g}$ for 10 minutes. Total $500 \mu \mathrm{l}$ volume of clarified cell culture supernatant was added to $500 \mu \mathrm{l}$ of phenol/chloroform/isoamyl alcohol (25:24:1) solution and 
then $50 \mu \mathrm{l}$ of $3 \mathrm{M}$ sodium acetate $(\mathrm{pH} 5.2)$ was added to it, pipette to mix and hold for $15 \mathrm{~min}$ in ice. To separate out the aqueous phase it was centrifuged at $12280 \mathrm{~g}$ for $10 \mathrm{~min}$ at room temperature. Aqueous layer was collected to a new centrifuge tube and added equal volume of isopropanol to it. After keeping at $-20^{\circ} \mathrm{C}$ for $5 \mathrm{~min}$, it was centrifuged at $10460 \mathrm{~g}$ for $5 \mathrm{~min}$ at $4^{\circ} \mathrm{C}$ to pellet the viral DNA. Subsequently, supernatant was discarded and pellet washed with $500 \mu \mathrm{l}$ of $70 \%$ ethanol at $14240 \mathrm{~g}$ for 3 minutes. Thereafter, the pellet was placed for air dried for at least 30 min. Finally, the pellet was dissolved in $40 \mu \mathrm{l}$ of nuclease free water and stored at $-20^{\circ} \mathrm{C}$ prior to use.

\section{Protocol 2: Viral DNA isolation using cell lysis buffer method}

After two cycles of freezing and thawing, harvested samples from SPPV infected cell culture were boiled for 10 min for coagulation of proteins, centrifuged at $12280 \mathrm{~g}$ for 15 minutes to remove the cell debris. Total $500 \mu$ l volume of boiled supernatant was added to equal volume of lysis buffer [500mM NaCl, $400 \mathrm{mM}$ tris- $\mathrm{HCl}$ (pH7.5), 1\% SDS, 50mM EDTA], incubated for $30 \mathrm{~min}$ at room temperature and centrifuged at $12280 \mathrm{~g}$ for $5 \mathrm{~min}$. About $850 \mu \mathrm{l}$ of supernatant was transferred into a fresh centrifuge tube and added, equal volume of isopropanol, kept at $-20^{\circ} \mathrm{C}$ for $20 \mathrm{~min}$ and again centrifuged at $12280 \mathrm{~g}$ for $5 \mathrm{~min}$ at $4^{\circ} \mathrm{C}$ to get the DNA pellet. Then, pellet was washed with $70 \%$ ethanol at $4240 \mathrm{~g}$ for 3 min at room temperature. The DNA pellet was air dried for $30 \mathrm{~min}$ and resuspended in $40 \mu \mathrm{l}$ of nuclease free water (NFW), and stored at $-20^{\circ} \mathrm{C}$ prior to use.

\section{Protocol 3: Viral DNA isolation using Proteinase-k method}

SPPV infected cell culture was harvested, centrifuged at $1820 \mathrm{~g}$ for $10 \mathrm{~min}$, and collected the supernatant. One $\mathrm{ml}$ of supernatant (final virus harvest concentration $0.1 \%$ ) was taken into $1.5 \mathrm{ml}$ centrifuge tube and added $10 \mu \mathrm{l}$ of $10 \% \mathrm{SDS}$, $20 \mu \mathrm{g} / \mathrm{ml}$ of Proteinase-k added and incubated in water bath at $37^{\circ} \mathrm{C}$ for $3 \mathrm{~h}$. Thereafter, the enzyme was inactivated by heating the sample at $65^{\circ} \mathrm{C}$ for $20 \mathrm{~min}$. After that, an equal volume of buffered saturated phenol was added and shaken vigorously for about $3 \mathrm{~min}$, and then centrifuged at $1420 \mathrm{~g}$ for $5 \mathrm{~min}$ to separate layers. Next, the upper aqueous layer was collected into a fresh $1.5 \mathrm{ml}$ centrifuge tube and to it equal volume of chloroform was added, and then shaken vigorously. The same procedure of centrifugation at $1420 \mathrm{~g}$ for $5 \mathrm{~min}$ was done and the upper aqueous layer aspirated into a fresh $1.5 \mathrm{ml}$ centrifuge tube, and added $3 \mathrm{M}$ sodium acetate $\left(1 / 10^{\text {th }}\right.$ of total volume). Subsequently, add $100 \%$ ethanol (in double volume) and tube was shaken gently for few seconds before keeping it at $-20^{\circ} \mathrm{C}$ for $30 \mathrm{~min}$, thereafter, the sample was centrifuged at $14240 \mathrm{~g}$ for $5 \mathrm{~min}$, and washed the pellet with $500 \mu \mathrm{l}$ of $70 \%$ ethanol for $3 \mathrm{~min}$ at $14240 \mathrm{~g}$. Finally, the DNA pallet was air dried and further resuspended in $80 \mu \mathrm{lNFW}$, and stored at $-20^{\circ} \mathrm{C}$ prior to use.

Protocol 4: Commercial viral nucleic acid extraction kit

DNA of SPPV was isolated following the protocol mentioned in user's manual of the commercial kit. Care was taken to isolate DNA from $1 \mathrm{ml}$ of the infected SPPV harvested culture and eluted in $80 \mu$ l of the elution buffer and stored at $-20^{\circ} \mathrm{C}$ prior to use.
PCI method (Protocol 1)

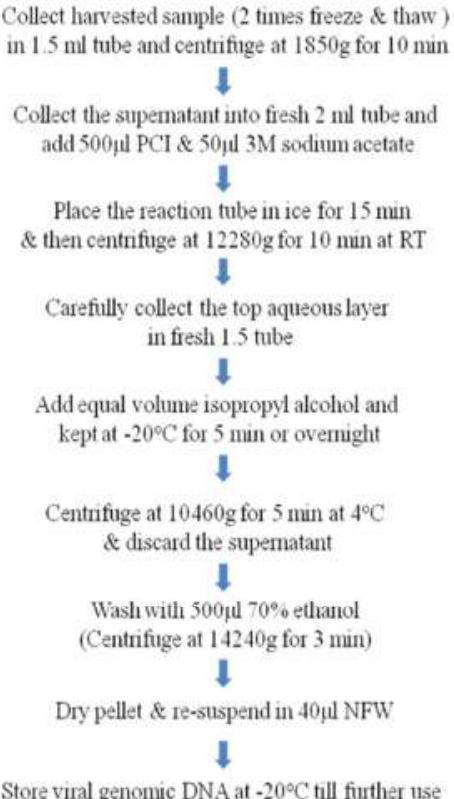

Lysis method (Protocol 2)

Collect harvested sample ( 2 times freeze \& thaw ) $\&$ boiled for $10 \mathrm{~min}$ 1 Centrifuge at $12280 \mathrm{~g}$ for $15 \mathrm{~min}$ 1 Add $500, \mathrm{ul}$ lysis buffer and incubate for $30 \mathrm{~min}$ at $\mathrm{RT}$ 1

Centrifuge at $12280 \mathrm{~g}$ for $5 \mathrm{~min}$

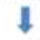

Collect supematant in fresh tube and add equal volume isopropyl alcohol 1

Kept at $-20^{\circ} \mathrm{C}$ for $20 \mathrm{~min}$ $\&$ then centrifuge at $12280 \mathrm{~g}$ for $5 \mathrm{~min}$ at $4^{\circ} \mathrm{C}$ 1

Pellet wash with 500 u $70 \%$ ethanol (Centrifuge at $14240 \mathrm{~g}$ for $3 \mathrm{~min}$ at RT) 1

Dry pellet \& re-suspend in $40 \mu \mathrm{l}$ NFW $\downarrow$

Store viral genomic DNA at $20^{\circ} \mathrm{C}$ till further use
Proteinase K method (Protocol 3)

Collect harvested sample ( 2 times freeze \& thaw) \& centrifuge at $1820 \mathrm{~g}$ for $10 \mathrm{~min}$

\section{$\downarrow$}

Collect supematant into fresh 15 tube \& Add $10 \mu \mathrm{ll} 10 \%$ SDS \& $20 \mu \mathrm{g} / \mathrm{ml}$ of Proteinase-k. Incubate at $37^{\circ} \mathrm{C}$ for $3 \mathrm{~h}$ in water bath 1

Thereafter, sample kept at $60^{\circ} \mathrm{C}$ for $20 \mathrm{~min}$ for enzyme inactivation 1

Add equal volume saturated Phenol \& shake vigorously for $3 \mathrm{~min}$, \& centrifige at $1420 \mathrm{~g}$ for $5 \mathrm{~min}$ 1

Collect the upper aqueous layer into a fresh $1.5 \mathrm{ml}$ tube \& Add equal volume chloroform \& shake vigorously 1

Centrifuge at $1420 \mathrm{~g}$ for $5 \mathrm{~min}$ and collect upper aqueous layer into $1.5 \mathrm{ml}$ tube 1

Add $1 / 10 \mathrm{vol} 3 \mathrm{M}$ sodium acetate $\& 2 \mathrm{vol} 100 \%$ ethanol, \& shake vigorously for $10-20$ seconds $\downarrow$

Kept tube at $-20^{\circ} \mathrm{C}$ for $30 \mathrm{~min}$ and centrifuge at $14240 \mathrm{~g}$ for $5 \mathrm{~min}$ $\downarrow$

Pellet wash with $500 \mathrm{\mu l} 70 \%$ ethanol (centrifuge at $14240 \mathrm{~g}$ for $3 \mathrm{~min}$ ) 1

Dry pellet \& re-suspend in 40ul NFW

$\&$ Store viral genomic DNA at $20^{\circ} \mathrm{C}$ till further use

Figure 1. Outlines of different viral DNA extraction methods 


\section{Characterization of isolated viral DNA}

The quantity of DNA samples was determined by measuring the absorbance at $260 \mathrm{~nm}$ and the purity of DNA samples was also checked by measuring the $\mathrm{OD}_{260} / \mathrm{OD}_{280}$ value using a Nanodrop spectrophotometer (Nanodrop 1000, Thermo Fisher Scientific, Singapore). Whereas, the gel electrophoresis was done to check the DNA integrity as well as its purity on $1 \%$ agarose gel.

\section{Confirmation of virus infection using PCR}

Purified SPPV DNA, as a template was taken and amplified with RNA polymerase subunit 19 gene (RPO19) specific primers (Table 1) using PCR. The final PCR reaction mixture $(25 \mu \mathrm{l})$ was containing of $2.5 \mu \mathrm{l}$ of $10 \mathrm{X}$ PCR reaction buffer, 0.05 units/ $\mu$ Taq DNA Polymerase
(GeNet Bio, Korea), 20 mM Magnesium Chloride (GeNet Bio, Korea), 10mM of each dNTP (dATP, dCTP, dGTP and dTTP); $0.5 \mu \mathrm{l}$ of each forward and reversed primer (10 picomole each), 50ng of template DNA, and makeup the final volume of $25 \mu \mathrm{l}$ with NFW. The PCR cycling conditions were as follows: $95^{\circ} \mathrm{C}$ for $5 \mathrm{~min}, 30$ cycles of $94^{\circ} \mathrm{C}$ for $30 \mathrm{sec}, 49^{\circ} \mathrm{C}$ for $30 \mathrm{sec}, 72^{\circ} \mathrm{C}$ for $30 \mathrm{sec}$ followed by $72^{\circ} \mathrm{C}$ for $7 \mathrm{~min}$.

\section{Statistical analysis}

The data were analyzed by one-way ANOVA using the General Linear Model procedure (IBM SPSS softeware20). The Tukey post-hoc analysis was done to test the significant mean differences between the groups with significance level defined at $\mathrm{P}<0.05$.

Table 1. Oligonucleotide primer pair used for RPO19 gene amplification using polymerase chain reaction.

\begin{tabular}{lccc}
\hline Primer sequence $\left(5^{\prime} \rightarrow 3^{\prime}\right)$ & Length $(\mathrm{bp})$ & Anneal. Temp* $\left({ }^{\circ} \mathrm{C}\right)$ & Amplicon size $(\mathrm{bp})$ \\
\hline F-GACGAAGATGCGAGTGATGA & 20 & 49 & 410 \\
R-TCTGTTACGGATAACAATTCTCCA & 24 & & \multirow{2}{*}{4} \\
\hline
\end{tabular}

RPO19: RNA polymerase subunit19 gene; *Annealing Temperature

\section{Results and discussion}

\section{Cell culture and SPPV infection}

The LTC/Vero cells (80-90\% confluent) were infected with SPPV strains (Jaipur strain, Roumanian Fanar, and Ranipet strain) at 1.0 MOI. The cytopathic effect (CPE) of SPPV Jaipur, SPPV Roumanian Fanar and SPPV Ranipet in
LTCs was observed at $24 \mathrm{~h}, 48 \mathrm{~h}, 72 \mathrm{~h}$, and $92 \mathrm{~h}$ post infection (Fig 2). Similarly, the CPE of SPPV Jaipur and SPPV Roumanian Fanar in Vero cells was also observed at 24h, $48 \mathrm{~h}, 72 \mathrm{~h}$, and $92 \mathrm{~h}$ post infection (Fig 3 ). It was observed that the CPE initially appeared at $24 \mathrm{~h}$ post infection and thereafter, the CPE was clearly observed at 48h, $72 \mathrm{~h}$ and $96 \mathrm{~h}$ post infection as shown in Fig 2 and Fig 3.
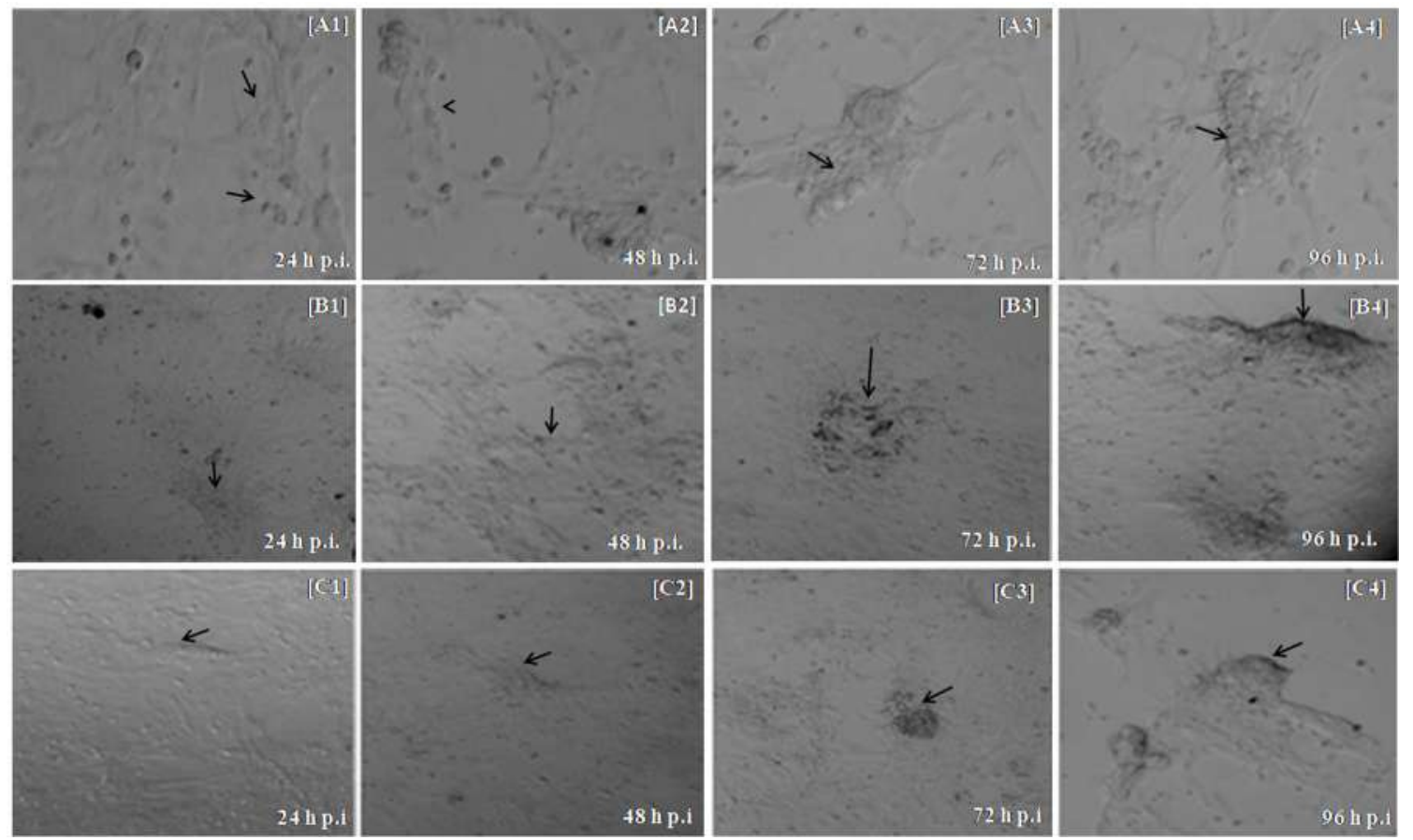

Figure 2. Primary lamb testis cell (LTC) culture infected with sheeppox virus (SPPV) Jaipur, SPPV Roumanian Fanar and SPPV Ranipet. Cytopathic effect of SPPV Jaipur in LTC observed at 24 hpi (Fig 2 A1; 20X), 48 hpi (Fig 2 A2; 20X), 72 hpi (Fig 2 A3; 20X) and 96 hpi (Fig 2 A4; 20X). Cytopathic effect in SPPV Roumanian Fanar infected LTC culture observed at 24 hpi (Fig 2 B1; 10X), 48 hpi (Fig 2 B2; 20X), 72 hpi (Fig 2 B3; 20X) and 96 hpi (Fig 2 B4; 20X). Fig 2 C1C4 shown the cytopathic effect in SPPV Ranipet infected LTC culture at 24 hpi (20X), 48 hpi (20X), 72 hpi (20X) and 96 hpi (20X), respectively. Arrow indicated the cytopathic effect. *p.i.: Post Infection 

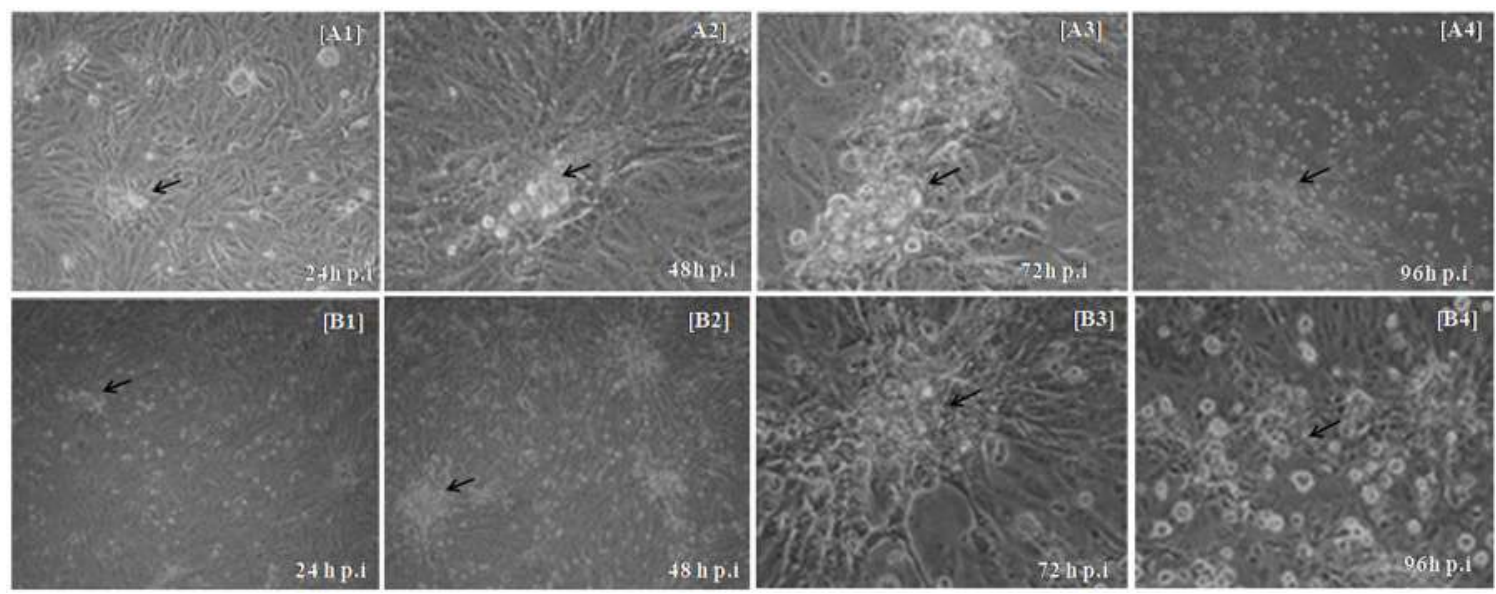

Figure 3. Vero cell line culture infected with SPPV Jaipur and SPPV Roumanian Fanar. Cytopathic effect of SPPV Jaipur in Vero cell culture observed at 24 hpi (Fig 3 A1; 20X), 48 hpi (Fig 3 A2; 20X), 72 hpi (Fig 3 A3; 40X) and 96 hpi (Fig 3 A4;10X). Fig 3 B1-B4 represented the cytopathic effect in SPPV Roumanian Fanar infected Vero cell culture at 24 hpi (10X), 48 hpi (10X), 72 hpi (40X) and 96 hpi (20X), respectively. Arrow indicated the cytopathic effect. *p.i.: Post Infection

\section{Evaluation of different DNA extraction methods for viral genomic DNA}

To obtain maximum viral genomic DNA yield in respect of purity and quantity from SPPV infected cell culture, four different types of DNA extraction methods were used and evaluated in this study. Before viral genomic DNA isolation, all intra-cellular mature virion (IMV) particles from all virus infected LTC/Vero cells culture were released by disrupting the infected cells following two rounds of freezing and thawing of harvested samples, and then extracted the viral genomic DNA using four different DNA extraction methods. In this study, the harvested SPPV strains i.e., SPPV-Jaipur, SPPV-RF and SPPV-Ranipet were used to infect $(1 \mathrm{MOI})$ the LTC/Vero cells and incubation at $37^{\circ} \mathrm{C}$ in $\mathrm{CO}_{2}$ incubator. At $80 \%$ of $\mathrm{CPE}$ and 4-5 days post infection virus was harvested, and subjected to isolation of viral genomic DNA using four different DNA extraction methods. Subsequently, the isolated DNA was characterized using gel electrophoresis and Nanodrop spectrophotometer. The integrity of DNA was checked on $1 \%$ agarose gel containing $0.5 \mu \mathrm{g} / \mathrm{ml}$ ethidium bromide. The DNA quantity and purity $\left(\mathrm{A}_{260 / 280}\right.$ ratio) were determined using a Nanodrop spectrophotometer.

The yield of genomic DNA extracted from virus infected cells harvest had shown the significant $(\mathrm{p}<0.05)$ difference among these four DNA extraction methods and the results are shown in Fig 4A-E. Out of these four methods, the protocol 3-Proteinase-k method which was based on enzymatic digestion of protein, found to yield significantly $(\mathrm{p}<0.05)$ higher quantity of SPPV genomic DNA (from SPPV Jaipur, SPPV RF and SPPV Ranipet in harvested LTC and Vero cell line culture) compared to other protocols (Fig 4A-E).In protocol 3 the use of Proteinase $\mathrm{K}$ helps to digest protein contamination during DNA isolation[20]. Proteinase $\mathrm{K}$ is a stable enzyme whose activity is substantially enhanced when denaturing chemicals like SDS are added [20, 21]. It degrades the nucleases present and protects nucleic acids from nuclease attack in DNA extraction. It is important that incubation of samples at a minimal temperature $37^{\circ} \mathrm{C}$ to an optimal temperature range between $50^{\circ} \mathrm{C}-65^{\circ} \mathrm{C}$ helps to unfolding many of proteins specially nucleases making easier for proteinase $\mathrm{K}$ to degrade them [22]. Proteinase $\mathrm{K}$ cleaves the peptide bond adjacent to the carboxyl group of $\mathrm{N}$ substituted hydrophobic, aliphatic, and aromatic amino acids. However, the protocol 4- commercial kit yielded good quality DNA but the yield was less as compared to other protocols. In addition, the other two methods viz. protocol 1-phenol/chloroform/isoamylalcohol (PCI) extraction and protocol 2-cell lysis buffer method significantly $(p<0.05)$ yielded around three times less viral genomic DNA than protocol 3 (Proteinase-k method). In the PCI method, the lipids and cellular debris are separated into the organic phase using a 25:24:1 combination of phenol, chloroform, and isoamyl alcohol, leaving isolated DNA in the aqueous phase [23]. Phenol denatures proteins by breaking the links between amino acids, whereas chloroform denatures lipid molecules and appropriately separates the aqueous and organic phases [24]. Isoamyl alcohol inhibits solution emulsification by reducing foaming between interphase [24]. The aqueous phase containing the isolated DNA can be transferred to a clean tube for analysis after centrifugation. In the precipitation process, sodium acetate and isopropanol react with DNA [25]. $\mathrm{Na}^{+}$and $(\mathrm{CH} 3 \mathrm{COO})^{-}$are formed when sodium acetate is broken down. The sodium ion, which is positively charged, neutralizes the DNA's negatively charged $\mathrm{PO}^{-}$. DNA's hydrophilic characteristic allows it to dissolve in water, but it becomes less hydrophilic when it reacts with sodium acetate[26]. To eliminate the salt in the pellet, $70 \%$ ethanol is employed, and the excess of salts dissolve in the $30 \%$ of water $[23,26]$. On the other side, mechanism behind the viral DNA isolation protocol 2 is incorporated with physical (mechanical and thermal) and chemical approaches. The boiling of harvested SPPV infected cell supernatant formed the protein coagulated. The component 
of lysis buffer contains buffering salt Tris-HCl, ionic salt $\mathrm{NaCl}$ that regulates the $\mathrm{pH}$ (ionic strength) in buffer and osmolarity of the lysate[26]. Detergent like SDS are organic amphipathic anionic surfactants which helps to separate/ break up the surface protein structures [24]. Additives like EDTA, the chelating agents blocks the activity of DNase enzymes and protected the DNA [26]. Moreover, this study also recorded the $260 / 280 \mathrm{~nm}$ absorbance ratio which was used to evaluate the purity of DNA. Significantly $(\mathrm{p}<0.05)$ higher $\mathrm{A}_{260 / 280}$ ratio value with average range $\sim 1.83,1.79,1.64$ and 1.38 was observed in protocol 3 (Proteinase-k method), protocol 4 (commercial kit), protocol 1 (phenol/chloroform/ isoamylalcohol extraction method) and protocol 2 (cell lysis buffer method), respectively. The $\mathrm{A}_{260 / 280}$ ratio value below 1.75 clearly indicated that the DNA sample is not pure that is contaminated with either traces of phenol or protein. Thus, the study was found significantly $(\mathrm{p}<0.05)$ better for SPPV genomic DNA yield and purity in protocol 3 compared to other DNA extraction methods although the $A_{260 / 280}$ ratio was better in protocol 4 but the yield was low. By using the protocol 3-proteinase $\mathrm{K}$ method, significantly $(\mathrm{p}<0.05)$ higher viral genomic DNA concentrations75.7 $\pm 3.2,67.4$ $\pm 3.09,53.3 \pm 3.12,542 \pm 4.7$ and $201 \pm 3.9 \mathrm{ng} / \mu \mathrm{l}$ were observed in SPPV Jaipur (in LTC), SPPV RF (in LTC), SPPV Ranipet (in LTC), SPPV Jaipur (in Vero cell) and SPPV RF (in Vero cell), respectively (Fig 4 A-E).

Molecular confirmation of SPPV infection in cell culture

To check whether the isolated DNA is free from PCR inhibitors or not, a gene fragment (RNA polymerase subunit 19 (RPO19) of SPPV was amplified using PCR at standardized cyclic conditions. The genomic DNA extracted by protocol 3 (proteinase-k method) from all the five SPPV samples showed good PCR amplification. As a result, the gene fragment that was amplified showed a good intense specific band (410 bp) on $1 \%$ agarose gel (Fig 4F) which indicated that the PCR inhibitors were absent. Bergallo et al., (27) study reported that the phenol/chloroform/ isoamylalcohol was found most effective method for polyoma $\mathrm{BK}$ virus in cell culture.
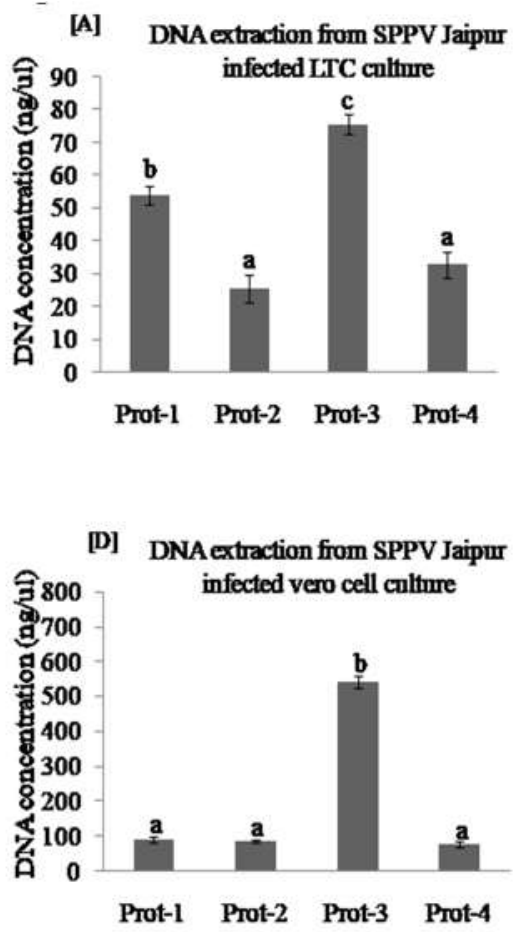
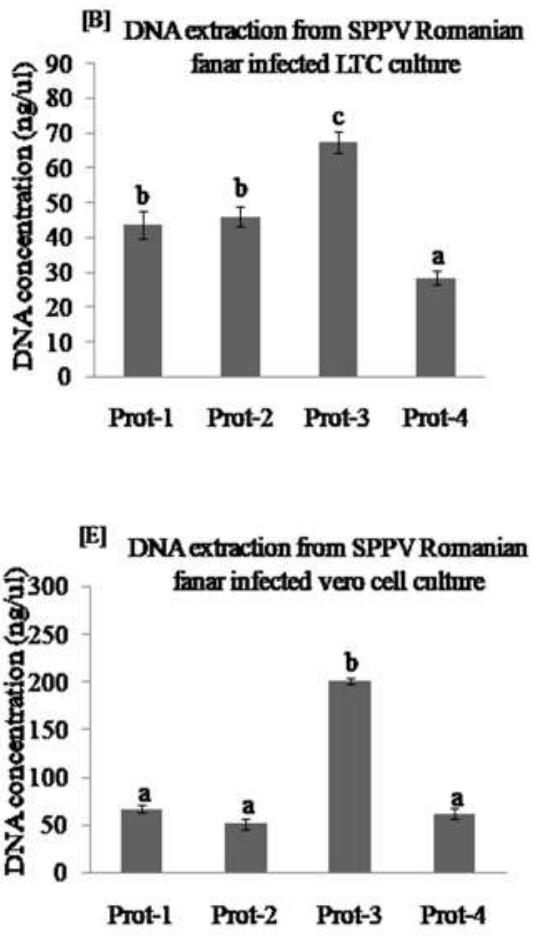
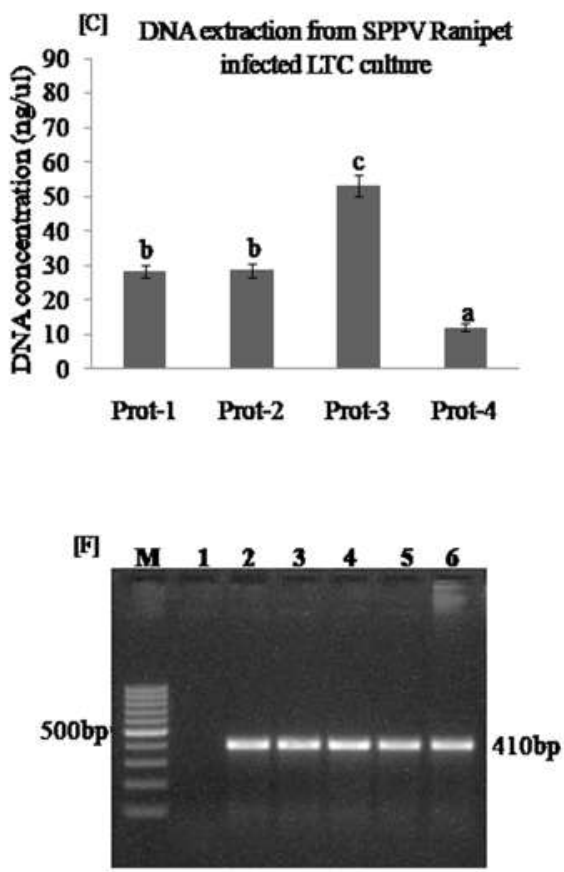

Figure 4. Genomic DNA extractions from the SPPV infected LTC/Vero cell culture using different DNA extraction methods. Using four different DNA extraction methods, the viral genomic DNA yield obtained from SPPV Jaipur infected LTC, SPPV RF infected LTC, SPPV Ranipet infected LTC, SPPV Jaipur infected Vero cell and SPPV RF infected Vero cell culture are shown in Fig 4A, Fig 4B, Fig 4C, Fig 4D and Fig 4E, respectively. SPPV infection in LTC/Vero cell culture harvest was confirmed by doing the PCR amplification of an RNA polymerase subunit 19 (RPO19) gene (product size 410 bp) of SPPV and the results are shown on 1\% agarose gel (Fig 4F). Lane M: 100 bp DNA ladder; Lane 1: negative control; Lane 2: SPPV Jaipur infected LTC, Lane 3: SPPV RF infected LTC; Lane 4: SPPV Ranipet infected LTC, Lane 5: SPPV Jaipur infected Vero cell and Lane 6: SPPV RF infected Vero cell culture. Prot-1: Phenol/chloroform/Isoamyl alcohol extraction method, Prot-2: Cell lysis buffer method, Prot-3: Proteinase-k method, Prot-4: Commercially available viral nucleic acid extraction kit-based method. Bar graphs bearing the same superscripts do not differ significantly. 


\section{Conclusion}

In this study, we evaluated four viral DNA extraction techniques for SPPV in cell culture, each with its unique set of principles and advantages. Our results demonstrated that the Proteinase-k extraction procedure was the most efficient in terms of yield and purity of SPPVgenomic DNA in LTC and Vero cell culture than other method used as a routine tool.

\section{Acknowledgment}

The authors would like to thank Sheeppox virus vaccine laboratory, Division of Biological Products, IVRI.

\section{Author's contribution}

$\mathrm{BM}$ and CLP conceived and designed the research. PM, JS, RS, IZ, BN, KB and AD conducted the wet lab work. PM, BM, CLP, JS and KD analyzed the data. PM, KD, JS, $\mathrm{BN}$ and $\mathrm{KB}$ helped in manuscript drafting and editing. BPM, BM and CLP proofread the manuscript.

\section{References}

1. BHANUPRAKASH V., INDRANI B., HOSAMANI M., et al. The current status of sheep pox disease. 29:27-60 (2006).

2. TULMAN E., AFONSO C., LU Z., et al. The genomes of sheeppox and goatpox viruses. 76:6054-6061(2002).

3. BHANUPRAKASH V., VENKATESAN G., BALAMURUGAN V., et al. Pox outbreaks in Sheep and Goats at Makhdoom (Uttar Pradesh), India: Evidence of Sheeppox Virus Infection in Goats. 57:375-382 (2010).

4. KITCHING RJDIB. Vaccines for lumpy skin disease, sheep pox and goat pox. 114:161-167 (2003).

5. TUPPURAINEN E., VENTER E.H., SHISLER J., et al. Capripoxvirus diseases: current status and opportunities for control. 64:729-745 (2017).

6. KALRA S.K., SHARMA V.K. Adaptation of Jaipur strain of sheeppox virus in primary lamb testicular cell culture. Indian journal of experimental biology, 19:165-169 (1981).

7. SAFINI N., BAMOUH Z., HAMDI J., et al. In-vitro and in-vivo study of the interference between Rift Valley fever virus (clone 13) and Sheeppox/Limpy Skin disease viruses. 11:1-12 (2021)

8. SONOWAL J., PATEL C.L., GANDHAM R.K., et al. Genome-Wide Expression Analysis Reveal Host Genes Involved in Immediate-Early Infections of Different Sheeppox Virus Strains. 145850 (2021).

9. HOSAMANI M., BHANUPRAKASH V., KALLESH D., et al. Cell culture adapted sheeppox virus as a challenge virus for potency testing of sheeppox vaccine. (2008).

10. LANTZ P.G., AL-SOUD W.A., KNUTSSON R., et al. Biotechnical use of polymerase chain reaction for microbiological analysis of biological samples. (2000).

11. MCORIST A.L., JACKSON M., BIRD ARJJOMM. A comparison of five methods for extraction of bacterial DNA from human faecal samples. 50:131139 (2002).

12. WIEDBRAUK D.L., WERNER J.C.,DREVON AMJJOCM. Inhibition of PCR by aqueous and vitreous fluids. 33:2643-2646 (1995).

13. ESPY M.J., PATEL R., PAYA C.V., et al. Comparison of three methods for extraction of viral nucleic acids from blood cultures. 33:41-44 (1995).

14. ESPOSITO J.J., KNIGHT J.C.J.V. Orthopoxvirus DNA: a comparison of restriction profiles and maps. 143:230-251 (1985).

15. EL-KHOLY A.A., SOLIMAN H.M., ABDELRAHMAN KAJAJOB. Polymerase chain reaction for rapid diagnosis of a recent lumpy skin disease virus incursion to Egypt. 11:293-302 (2008).

16. ZEEDAN G.S., MAHMOUD A.H., ABDALHAMED A.M., et al. Rapid Detection and Differentiation between Sheep Pox and Goat Pox Viruses by RealTime qPCR and Conventional PCR in Sheep and Goat in Egypt. 10:80-87 (2020).

17. SANTHAMANI R., YOGISHARADHYA R., VENKATESAN G., et al. Detection and differentiation of sheeppox virus and goatpox virus from clinical samples using $30 \mathrm{kDa}$ RNA polymerase subunit (RPO30) gene based PCR. 6:923 (2013).

18. REED L.J., MUENCH HJAJOE. A simple method of estimating fifty per cent endpoints. 27:493-497 (1938).

19. CHIFNEY S., MARTIN W., ERGIN H., et al. Factors associated with the production of attenuated sheep pox vaccines. 14:62-68 (1973).

20. QAMAR W., KHAN M.R., ARAFAH A. Optimization of conditions to extract high quality DNA for PCR analysis from whole blood using SDSproteinase K method. Saudi Journal of Biological Sciences 24:1465-1469 (2017).

21. CHACON-CORTES D., HAUPT L.M., LEA R.A., et al. Comparison of genomic DNA extraction techniques from whole blood samples: a time, cost and quality evaluation study. Molecular Biology Reports 39:5961-5966 (2012).

22. SCHANDER C., KENNETH H.M. DNA, PCR and formalinized animal tissue - a short review and protocols. Organisms Diversity \& Evolution 3:195205 (2003).

23. TAN S.C., YIAP B.C. DNA, RNA, and protein extraction: the past and the present. J Biomed Biotechnol 2009:574398 (2009).

24. SHEN C.H. Chapter 6 - Extraction and Purification of Nucleic Acids and Proteins, in Diagnostic Molecular Biology. Edited by Shen C-HAcademic Press, pp 143-166 (2019).

25. SAMBROOK J., FRITSCH E.F., MANIATIS T. Molecular cloning: a laboratory manual, Cold spring harbor laboratory press, (1989).

26. HEIKRUJAM J., KISHOR R., MAZUMDER PBJBATMFB-MS. The chemistry behind plant DNA isolation protocols. 8 (2020).

27. BERGALlO M., COSTA C., GRIBAUDO G., ET AL. Evaluation of six methods for extraction and purification of viral DNA from urine and serum samples. 29:111-119 (2006). 